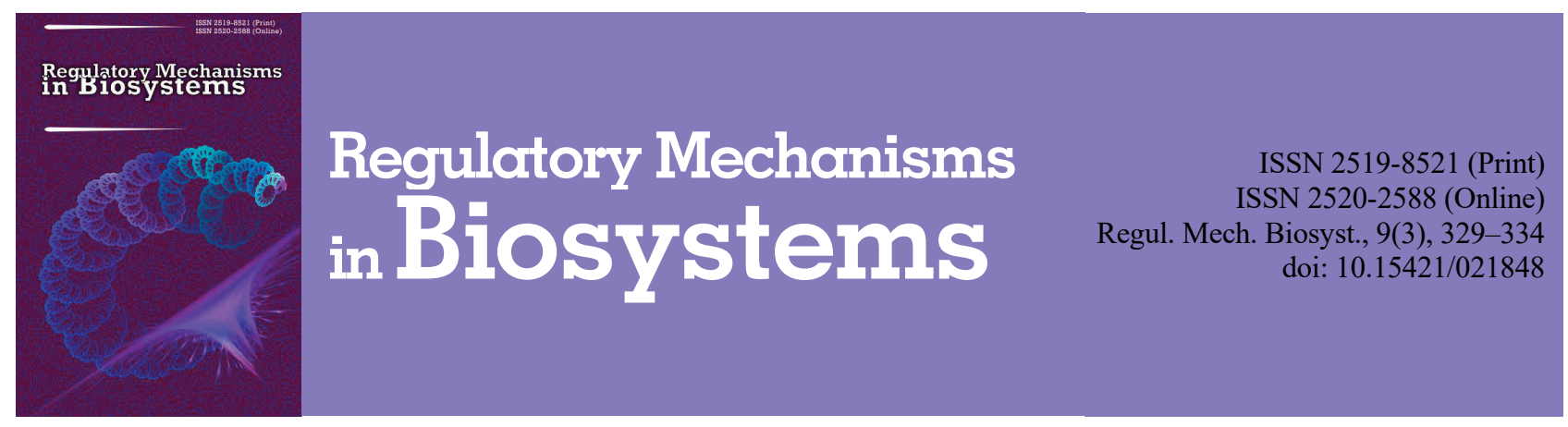

\title{
The parasitofauna of the Siberian sterlet Acipenser ruthenus marsiglii of the Lower Irtysh
}

\author{
E. L. Liberman*, E. L. Voropaeva** \\ *Tobolsk Complex Scientific Station UD RAS, Tobolsk, Russia \\ **Center for Parasitology of the A. N. Severtsov Institute of Ecology and Evolution of the RAS, Moscow, Russia
}

Article info

Received 19.05.2018

Received in revised form 24.06.2018

Accepted 28.06.2018

Tobolsk Complex

Scientific Station UD RAS

Y. Osipova st., 15 ,

Tobolsk, 626152,

Russian Federation

Tel.: +7-905-826-23-47

E-mail:

eilat-tymen@mail.ru

Center for Parasitology

of the A. N. Severtsov

Institute of Ecology

and Evolution of the RAS,

Leninsky Prospect, 33,

Moscow, 119071,

Russian Federation.

Tel.: +7-925-509-40-96

E-mail:kts2@yandex.ru

\section{Liberman, E. L., \& Voropaeva, E. L. (2018). The parasitofauna of the Siberian sterlet Acipenser ruthenus marsiglii of the Lower Irtysh. Regulatory Mechanisms in Biosystems, 9(3), 329-334. doi:10.15421/021848}

In the Ob-Irtysh basin, studies on the parasitofauna of the Siberian sterlet are very limited and confined to the middle of the twentieth century. The decrease in the numbers of sterlet over the past half century may have led to a change in the qualitative and quantitative composition of the parasitofauna. The aim of this work is to study the parasitofauna of the Siberian sterlet in the rivers Irtysh and Tobol. 85 specimens of Siberian sterlet $(\mathrm{L}=27.8-51.5 \mathrm{~cm}, 2+-6+)$ from the Tobol and Irtysh rivers were examined by the method of complete parasitological dissection during the periods from 5 to 21 June and from 14 to 22 July 2017. A comparison of the biodiversity of parasites was performed using the indices: Berger-Parker. 11 species of parasites were found, including four species specific to sturgeons: Cryptobia acipenseris (Joff, Lewashow, Boschenko, 1926), Haemogregarina acipenseris (Nawrotzky, 1914), Crepidostomum auriculatum (Wedl, 1858), Capillospirura ovotrichura (Skrjabin, 1924). Seven broadly specific species: Trichodina sp., Proteocephalus sp. (plerocercoids), Diplostomum chromatophorum mtc. (Vrown, 1931), Echinorhynchus cinctulus (Porta, 1905), Piscicola geometra (Linnaeus., 1761), Ergasilus sieboldi (Nordmann, 1832), Unionidae gen. sp. Cryptobia acipenseris and $H$. acipenseris were recorded for the first time in the Ob-Irtysh basin. C. acipenseris was found only in three fish from the total number of examined sterlet (3.5\%). In the River Tobol the extent of infestation H. acipenseris was higher $(22.7 \%)$ than in the River Irtysh $11.1 \%$. The carriers of C. acipenseris and H. acipenseris in the Lower Irtysh are allegedly leeches of Piscicola geometra $(10.6 \%)$. The most common parasites found were $C$. auriculatum $(32.9 \%)$ and C. ovotrichura (15.3\%). In the River Irtysh, metacercariae of Diplostomum chromatophorum (Vrown, 1931) (metacercariae) were discovered in the lens of the eye in the studied fish. The maximum EI of this parasite was noted in the fish sample near the city of Tobolsk $-12.5 \%$ with AI -1 and IO - 0.12. In the Gornoslinkino area in June and July, the infection level was low (EI 4.3\% and 8.3\%, respectively). In the June sample of fish from the River Tobol no metacercariae of this species were detected. Single cases of infection of Proteocephalus sp. (plerocercoid), E. cinctulus, E. sieboldi, Unionidae gen. sp. were found. In the River Irtysh the parasitofauna was dominated by C. ovotrichura, in the River Tobol - C. auriculatum. The number of parasite species noted in the Siberian sterlet in the Ob-Irtysh basin according to our own and literary data is greater than that found in sterlet from the River Yenisei: 18 and 11 respectively. Common to the sterlet of the two basins are 8 species of parasites: Cryptobia acipenseris, Diclybothrium armatum, Crepidostomum auriculatum, Capillospirura ovotrichuria, Truttaedacnitis clitellarius, Echinorhynchus cinctulus, Piscicola geometra, Unionidae gen. sp. The fauna of the Ob-Irtysh basin was enriched by the "southern" narrowly specific parasite of sturgeon $-H$. acipenseris. For many years the infection of $C$. auriculatum has practically not changed.

Keywords: parasites; Haemogregarina acipenseris; Cryptobia acipenseris; Capillospirura ovotrichuria; Siberian sterlet; Tobol; Irtysh.

\section{Introduction}

Sturgeons are one of the oldest groups of fish, the biology and cultivation of which is a subject of interest all around the world (Guénette et al., 1992; Israel \& May, 2010; Wuertz et al., 2011; Akbulut et al., 2013; Vasil'ev et al., 2014). The smallest representative of sturgeons is the sterlet (Acipenser ruthenus (Linnaeus, 1758)). It is a nonmigratory species, inhabits the rivers of the following basins: Azov, Caspian, Black, Adriatic and Baltic seas, and also the Northern Dvina River and its tributaries - Suhona and Vychegda. It is common in the basins of the Siberian rivers: $\mathrm{Ob}$ and Yenisei, where it forms a subspecies Acipenser ruthenus marsiglii (Brandt, 1833) (Zhuravlev, 2000). Sterlet quite like warm water, winter in river pockets, and are typical benhtophages - the basis of their food is chironomid larvae, Simuliidae, mayflies, dragonflies, molluscs, and other representatives of macrozoobenthos (Strel'nikova, 2012). Because of the high industrial value of sterlet, and therefore their intensive fishing, and also change in hydrological and hydrochemical regimes of water bodies (places of spawning and fattening), by the end of the 1970s, the reserves of sterlet in the ObIrtysh basin had become critical (Liberman, 2017). Currently, there is no industrial fishing of sterlet in this basin, catching takes place only for scientific purposes.

Studies on the morphology and biology of parasites of sturgeons in natural and artificial water bodies have been conducted by a number of scientists (Appy \& Anderson, 1982; George \& McCabe, 1993; Choudhury \& Dick, 2001; Sepúlveda et al., 2010; Lysenko, 2013). The species composition of the parasitofauna of the sterlet has been best studied in the Volga basin, where the species is represented by the nominative subspecies (Dubinin, 1952; Ivanov, 1968; Izyumova, 1977; Lyubarskaya \& Lavrent'eva, 1985; Fedotkina \&, Shinkarenko, 2015). In the rivers of the basins of the Azov and the Black seas, parasites of sterlet were studied by Kazarnikova \& Shestakovskaya (2006), Cakic et al. (2008), 
Lenhardt et al. (2009). Parasites of sterlet have been well studied in the Yenisei and Ob-Irtysh basins (Zahvatkin, 1938; Volkova, 1941; Bauer, 1948; Petrushevskij et al., 1948; Shul'man, 1954; Dobrohotova, 1960; Titova, 1965; Skryabina, 1974). However, the last publication with original data on sterlet parasites in the Ob-Irtysh basin was published more than 50 years ago (Titova, 1965).

The decrease in the number of sterlet over the last half-century could have led to change in qualitative and quantitative composition of their parasitofauna. Therefore, due to absence of the corresponding studies over many years, the presentation of new data on the species composition of parasites of sterlet is relevant.

The objective of this research was to study the current condition of the parasitofauna of the Siberian sterlet in the Irtysh and Tobol rivers.

\section{Materials and methods}

The material was collected during the periods from 5 th to 21 st June and from 14th to 22st July of 2017 from the Tobol and Irtysh rivers, located within the Tobol and Uvatsky districts of the Tyumen oblast.

Using the method of full parasitological autopsy, we examined 85 specimens of sterlet: 22 specimens with absolute body length (L) $30.8-51.5 \mathrm{~cm}$ from the Tobol River (Karachino village, $58^{\circ} 02^{\prime} 50^{\prime \prime} \mathrm{N}$, $68^{\circ} 065^{\prime \prime}$ E; June), 23 specimens with $\mathrm{L}=29.2-37.6 \mathrm{~cm}$ from the Irtysh near Gornoslinkino village (58 $43^{\prime} 54^{\prime \prime} \mathrm{N}, 68^{\circ} 41^{\prime} 54^{\prime \prime} \mathrm{E}$; June), 24 specimens with $\mathrm{L}=27.8-36.2 \mathrm{~cm}$ from the Irtysh near Gornoslinkino (July) and 16 specimens with $\mathrm{L}=31.5-46.0 \mathrm{~cm}$ from the Irtysh in the area of the city of Tobolsk (58 $11^{\prime} 04^{\prime \prime} \mathrm{N}, 68^{\circ} 12^{\prime} 59^{\prime \prime} \mathrm{E}$; July). We studied individuals of different sex and age range $2+-6+$.

Full parasitological analysis, standard methods of fixation and staining of parasites were conducted according to the methods of I. E. Byhovskaya-Pavlovskaya (1985). Blood was drawn from the tail vein, a smear was prepared, dried in the air, and then fixated in a mixture of 95\% ethyl spirit and diethyl ether $(1: 1)$ during 30 minutes, the fixated smears were then dried in the air at room temperature, stained using azure-eosine in a $1: 10$ solution during 40 minutes. For identifying the nematodes, we used the work of Moravec (2013), for the remaining groups of parasites - identification guides to parasites of fresh water fish of the fauna of the USSR (Opredelitel' ..., 1984, 1987).

We calculated the extensity of the invasion (EI, \%), intensity of the invasion (II, minimum - maximum, specimens), abundance index (AI, specimens per fish), for intra-erythrocytic parasites - parasitemia index (X) (Bush et al., 1997; Woo et al., 2006).

$$
E=\frac{n}{N} \times 100 \% \text {; }
$$

where $E$ - invasion extensivity, $n$ - number of host individuals infested with parasites, $N$-number of studied host individuals.

$$
M=\frac{m}{N}
$$

where $M-$ abundance index, $m$ - number of parasites found in the studied selection of hosts, $N$-number of examined host individuals.

$$
X=\frac{A}{B \times C} \times 100 \%
$$

where $A$ - number of affected erythrocytes, $B$ - number of erythrocytes in one microscope field, $C$-number of examined microscope fields. No less than 50 microscopic fields were examined for each preparation.

For identifying the dominant species in the communities, we used the Berger-Parker dominance index (d) (Mehgarran, 1992):

$$
d=\frac{\mathrm{Nmax}}{\mathrm{N}}
$$

where $N_{\max }$ - number of the most abundant species, $N$ - total number of parasites in the community.

\section{Results}

In the basin of the Lower Irtysh, the Siberian sterlet was found to have 11 species of parasites (Table 1), represented by different systematic groups: Ciliophora - 1, Kinetoplastida - 1, Apicomplexa - 1, Cesto$\mathrm{da}-1$, Trematoda -2 , Chromadorea - 1, Palaeacanthocephala - 1, Hirudinea -1 , Copepoda -1 , Bivalvia -1 . Among them, 4 species are specific to sturgeon - Cryptobia acipenseris (Joff, Lewashow, Bos- chenko, 1926), Haemogregarina acipenseris (Nawrotzky, 1914), Crepidostomum auriculatum (Wedl, 1858), Capillospirura ovotrichura (Skrjabin, 1924) (Table 1). Cryptobia acipenseris and the intra-erythrocytic parasite Haemogregarina acipenseris were found as a result of microscopic analysis of the smears. C. acipenseris (Fig. 1) was recorded in June, one specimen from the Tobol and in July, two specimens from the Irtysh (in one of each of the researched stretches). We assessed 2 4 parasites in each blood smear.

H. acipenseris has an oval body shape, is $6.5-8.2 \times 2.2-3.0 \mu \mathrm{m}$ in size, with two rounded ends or one rounded and one sharpened end (Fig. 2). The nucleus is composed of a few chromatin granules. It is positioned both in the middle of the body and in one of its ends. Most often, one parasite is found in an erythrocyte, more rarely two, and we also found parasites outside erythrocytes due to their decomposition. The highest EI of this parasite was recorded in a selection of fish caught in July in the Irtysh River in the area of Tobolsk - 31.2\% at average value of parasitemia of $0.06 \pm 0.02 \%$. The lowest EI was in fish caught in the same month in the Irtysh in the area of Gornoslinkino village $(8.3 \%)$ at average value of parasitemia equaling $0.12 \pm 0.11 \%$. The highest average values of parasitemia were observed in sterlet from the Tobol River $-0.19 \pm 0.13 \%$. It is interesting that these parasites were not found at all in the selection of fish from the Irtysh, collected in the same month as the fish from the Tobol (June).

\begin{tabular}{|c|c|c|c|c|c|c|c|}
\hline \multirow[b]{2}{*}{ Species of parasite } & \multirow[b]{2}{*}{ Localization } & \multicolumn{3}{|c|}{$\begin{array}{l}\text { The Tobol River } \\
\mathrm{n}=22 \text { specimens }\end{array}$} & \multicolumn{3}{|c|}{$\begin{array}{l}\text { The Irtysh River } \\
n=63 \text { specimens }\end{array}$} \\
\hline & & $\begin{array}{l}\text { EI, } \\
\%\end{array}$ & $\begin{array}{c}\text { II, } \\
\text { speci- } \\
\text { mens }\end{array}$ & $\begin{array}{c}\text { AI, } \\
\text { speci- } \\
\text { mens }\end{array}$ & $\begin{array}{l}\mathrm{EI}, \\
\%\end{array}$ & $\begin{array}{c}\text { II, } \\
\text { speci- } \\
\text { mens }\end{array}$ & $\begin{array}{c}\mathrm{AI}, \\
\text { speci- } \\
\text { mens }\end{array}$ \\
\hline Cryptobia acipenseris & blood & 4.5 & - & - & 3.2 & - & - \\
\hline $\begin{array}{l}\text { Haemogregarina } \\
\text { acipenseris }\end{array}$ & erythrocytes & 22.7 & - & - & 11.1 & - & - \\
\hline Trichodina sp. & $\begin{array}{l}\text { body surfa- } \\
\text { ce, fins, gills }\end{array}$ & 100.0 & - & - & 9.5 & - & - \\
\hline Proteocephalus sp., $\mathrm{p}$ & lintestine & - & - & - & 1.6 & 1 & 0.02 \\
\hline $\begin{array}{l}\text { Diplostomum chro- } \\
\text { matophorum, } \text { mtc }^{*}\end{array}$ & lens & - & - & - & 7.9 & 1 & 0.08 \\
\hline $\begin{array}{l}\text { Crepidostomum } \\
\text { auriculatum }\end{array}$ & intestine & 40.9 & $1-23$ & 3.1 & 30.2 & $1-36$ & 1.50 \\
\hline $\begin{array}{l}\text { Capillospirura } \\
\text { ovotrichura }\end{array}$ & stomach & 9.1 & $2-28$ & 1.4 & 17.5 & $1-93$ & 3.80 \\
\hline $\begin{array}{l}\text { Echinorhynchus } \\
\text { cinctulus }\end{array}$ & intestine & - & - & - & 1.6 & 1 & 0.02 \\
\hline Piscicola geometra & gills, fins & 4.5 & 1 & 0.04 & 12.7 & $1-2$ & 0.20 \\
\hline Ergasilus sieboldi & gills & - & - & - & 1.6 & 1 & 0.02 \\
\hline Unionidae gen. sp. & gills & - & - & - & 1.6 & 1 & 0.02 \\
\hline
\end{tabular}

\section{Table 1}

Species composition of parasites and parameters of infestation of Siberian sterlet in the Lower Irtysh basin

Note: EI - extensity of invasion, II - intensity of invasion min-max, AI abundance index, mtc - metacercariae, $\mathrm{pl}$ - plerocercoid, ${ }^{*}$ - larvae stage.

Crepidostomum auriculatum trematode (Fig. 3) and Capillospirura ovotrichura nematode (Fig. 4) were found in all examined selections of fish. All specimens found of C. auriculatum and C. ovotrichura were mature. The nematode parasitized mostly in the stomach, more rarely in the intestine, trematodes were found throughout the length of intestine. The highest infestation with C. auriculatum was recorded in fish from the Tobol River in June (Table 1). In the Irtysh, maximum EI equaled $37.5 \%$, with infestation intensity of 1-36 specimens per fish and AI-3.9 (area of Tobolsk, July). Maximum extensivity of infestation with Capillospirura ovotrichura was observed in fish from the Irtysh River near Gornoslinkino (July) $-25 \%$ at II of 1-21 specimens per fish and $\mathrm{AI}-1.7$, whereas maximum intensity of invasion -93 specimens per fish at 5.9 abundance index was recorded near Tobolsk (EI - 12.5\%). On the whole, Capillospirura ovotrichura is the most abundant parasite of sterlet in the Irtysh $(\mathrm{d}=0.680)$, whereas in the Tobol River, the dominant was Crepidostomum auriculatum trematode $(\mathrm{d}=0.690)$.

In the Irtysh river, in the lenses of the studied fish, we found Diplostomum chromatophorum (Brown, 1931) metacercariae. Maximum EI with this parasite was recorded in the fish selection from the area of 
Tobolsk $-12.5 \%$ and II -1 and $\mathrm{AI}-0.12$. In the area of Gornoslinkino in June and July, the infestation was low (EI $-4.3 \%$ and $8.3 \%$ respectively). In the June selection of fish from the Tobol River, no metacercariae of this species were found.

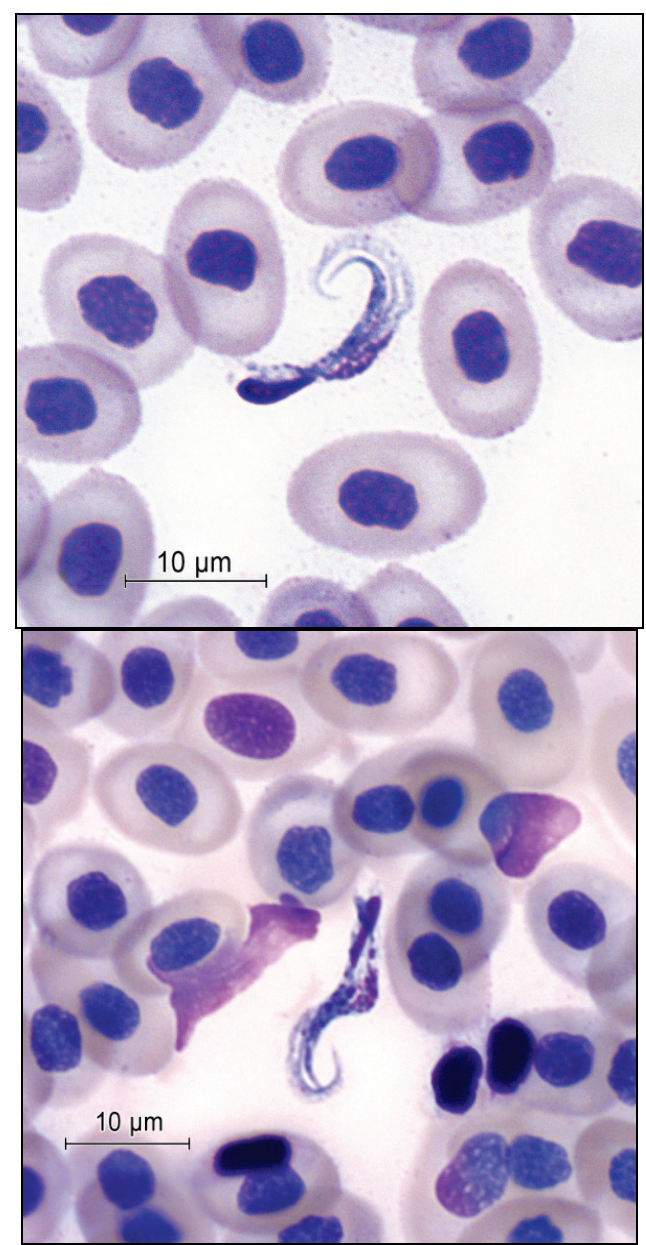

Fig. 1. Cryptobia acipenseris (Joff, Lewashow, Boschenko, 1926) in blood of Siberian starlet

Among the rest of the recorded species, parasites of sterlet which belong to Trichodina sp. were frequently found, parasitizing the body surface, gills and fins. The identification to species level was impossible due to the poor condition of the material. All fish species were infested with this parasite only in the June selection from the Tobol (Table 1). In each preparation of slime scrape, we found 1-3 trichodinids. At the same time, fish from the Irtysh (June) was found to be freer from this parasite. In July, in the Irtysh River, the extensity of invasion, depending on the area of the study, ranged from $8.3 \%$ (Gornoslinkino) to $25.0 \%$ (Tobolsk). Rare parasite species were Proteocephalus sp. cestode (plerocercoid), Diplostomum chromatophorum (Brown, 1931) trematode (metacercaria), Echinorhynchus cinctulus (Porta, 1905) acanthocephala (immature female), Ergasilus sieboldi (Nordmann, 1832) copepod crustacean, Piscicola geometra (Linnaeus, 1761) leech and Unionidae gen. sp. mollusc (glochidium).

\section{Discussion}

Most of the parasite species found (6) are reliably known to have a complex life cycle: Haemogregarina acipenseris, Proteocephalus sp., Diplostomum chromatophorum, Crepidostomum auriculatum, Capillospirura ovotrichura, Echinorhynchus cinctulus .Four species have a direct life cycle - widely distributed and insignificantly specific to any hosts: Trichodina sp., Piscicola geometra, Ergasilus sieboldi, Unionidae gen. sp.

Cryptobia acipenseri were recorded in different sturgeon in the basins of Don, Volga, Donau and Yenisei (Dubinin, 1952; Bauer et al., 2002). Most often, this parasite was recorded in sterlet (Shul'man, 1954;
Lyubarskaya \& Lavrent'eva, 1985; Baska, 1990; Bauer et al., 2002). According to Shul'man (1954), the range of $C$. acipenseris should coincide with the range of sterlet. However, the absence of data on the records of this parasite in the Ob-Irtysh basin could not prove this supposition. Our data verify the hypothesis of this author. The studies by Pazooki and Masoumian (2004), conducted on mature Acipenser gueldenstaedtii and A. persicus from the Caspian Sea, demonstrated a significantly different occurrence of Cryptobia acipenseri during examination of humid and stained blood smears (EI - 45\% and 55\% compared to $15 \%$ and $25 \%$ ). These authors recommend assessing the infestation of fish with kinetoplastids and flagellates by humid blood smears. The evidence presented by Pazooki and Masoumian (2004) should be checked by referring to additional material. The life cycle of $C$. acipenseri has not been studied completely. According to the literature data, transmission of Cryptobia to fish is possible by direct transmission from leeches (Woo, 2003).

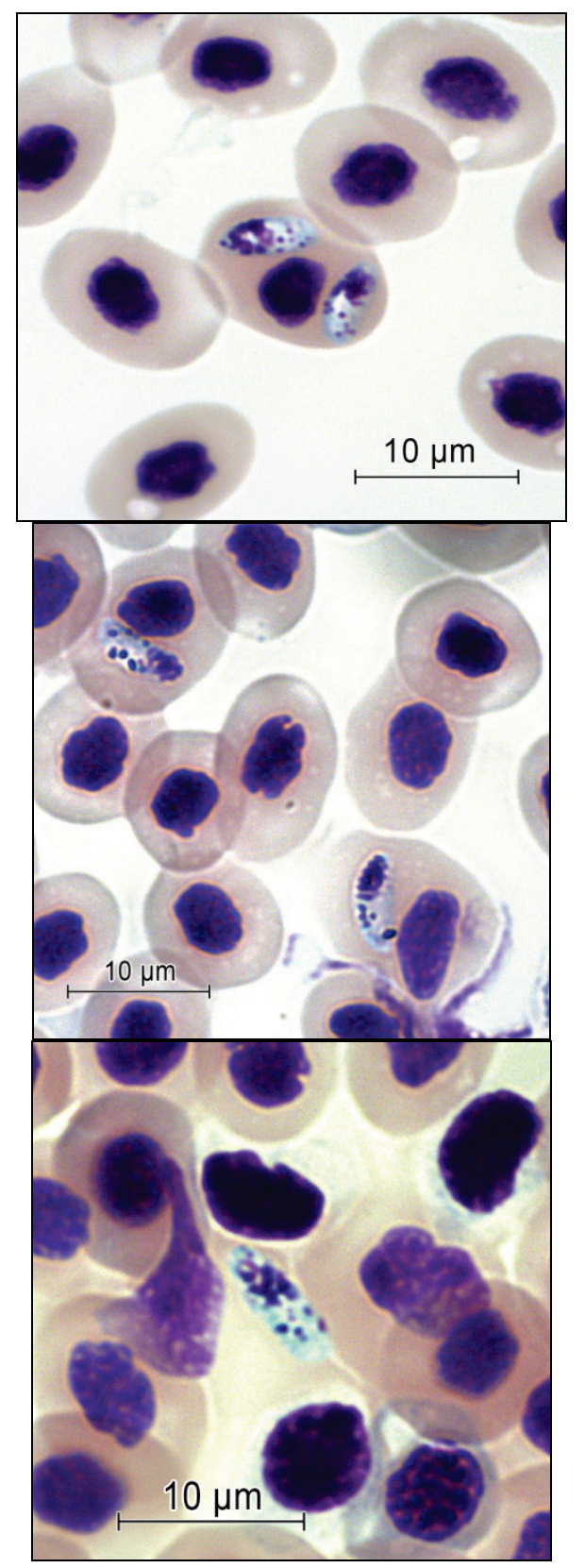

Fig. 2. Blood smears of Siberian sterlet with intra-erythrocytic Haemogregarina acipenseris (Nawrotzky, 1914)

Haemogregarina acipenseris was previously recorded only in sturgeon in the basin of the Caspian and the Black Seas. It was recorded in sterlet in the Volga and Danube (Perekropov, 1930; Baska, 1990), and also in Russian sturgeon and Persian sturgeon, and beluga from the 
Lower Volga, Northern and Southern Caspian Sea (Ivanov, 1968; Pazooki \& Masoumian, 2004). The sizes of $H$. acipenseris merozoites from Siberian sterlet coincide with equivalent parameters from Volga sterlet (Perekropov (1930), but significantly differ from merozoites from sturgeon (Pazooki \& Masoumian, 2004): 6.5-8.2 × 2.2-3.0 $\mu \mathrm{m}$ compared to $4.0-5.0 \times 1.5-3.0 \mu \mathrm{m}$. The identification of haemogregarine species found by Pazooki \& Masoumian (2004) needs to be proved.

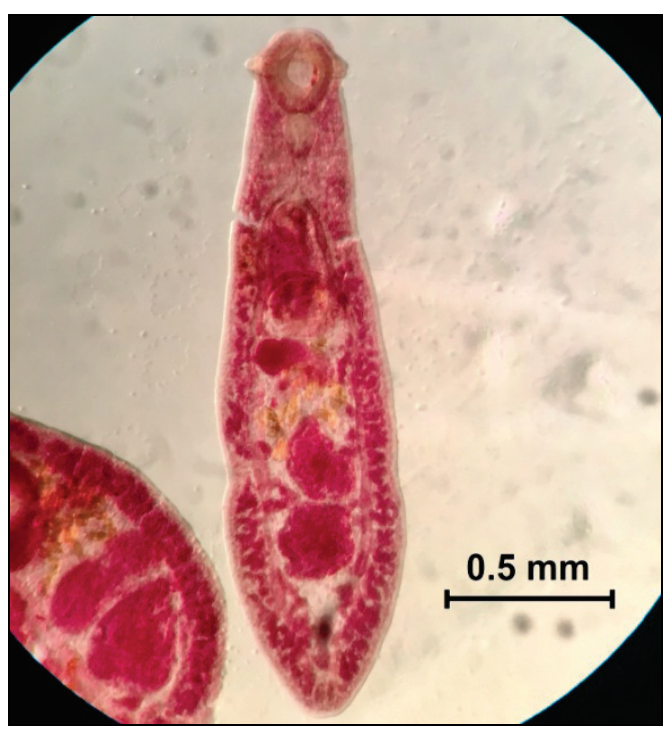

Fig. 3. Crepidostomum auriculatum (Wedl, 1858)

Perekropov (1930) thought that the entire life cycle of H. acipenseris takes place in the blood of sterlet. Shul'man (1954) doubted the reliability of this study, for he assumed that transmission of haemogregarines from one fish to another is not possible without participation of blood-sucking invertebrates. It seems that as a result of experimental studies, it was determined that haemogregarines of fish are transmitted by leeches of the Piscicolidae family (Khan, 1980; Woo, 2006). Carriers of $\mathrm{H}$. acipenseris in the Lower Irtysh are Piscicola geometra leeches, which were found on sterlets' pharyngeal arches and fins.

The most abundant helmiths of Siberian sterlet in the Lower Irtysh basin were $C$. auriculatum trematode and $C$. ovotrichura nematode, both specific to sturgeon. It should be mentioned that $C$. ovotrichura in the Irtysh basin were recorded earlier only in the Zaysan Lake (Zahvatkin, 1938; Dobrohotova, 1960). The distribution of these parasites coincides with the range of sturgeon (Skryabina, 1974; Appy \& Anderson, 1982). Molecular-genetic data do not prove that $C$. auriculatum belongs to the Crepidostomum (Braun, 1900) genus (Atopkin \& Shedko, 2014; Soldanova et al., 2017). The genus status of this parasite requires confirmation. Their life cycle is still incompletely studied. Presumably, the intermediary hosts for these species (the second for $C$. auriculatum and the only one for C. ovotrichura) are benthos invertebrates, particularly Gammaridae and mayfly larvae (Caira, 1989; Moravec, 1994). The Tobol River is a tributary of the Irtysh, there are both artificial and natural barriers between them, which limits the freedom of movement of fish between the water currents. The differences in the dominance of Crepidostomum auriculatum and Capillospirura ovotrichura in the Tobol and Irtysh are, perhaps, related to the intensity of consumption of the abovementioned components of the zoobenthos.

It is interesting that without an account of the abovementioned local differences, the extent of sterlet infestation with $C$. auriculatum in the Lower Irtysh was practically similar to that recorded by Petrushevskij et al. (1948) for this host in the region over 70 years ago (Table 2). Anderson (1982) demonstrated that a high number of the intermediary host when there is a decrease in the number of the final host leads to higher resistance of the "host - parasite" system than at increase in the number of the latter. And, if a higher number of parasite individuals concentrate in a small number of host individuals, then it is enough for survival of the parasites' population due to the larva forms which live in intermediary hosts (Anderson \& May, 1978; May \& Anderson, 1978).
Metacercariae of Diplostomum chromatophorum trematodes were recorded in Siberian sterlet for the first time. Infestation with this common and low-specific parasite was insignificant and causes no great damage to fish (Marcogliese et al., 2001; Voutilainen et al., 2008).

According to the literature data, sterlet in the Ob-Irtysh basin were found to host 11 species of parasites (Table 2), of which, 7 species were not observed by us : Hexamita truttae (Schmidt, 1920), Trichodina domerguei (Wallengren, 1897), Trichodina carassii (Dogiel, 1940), Diclybothrium armatum (Leuckart, 1835), Diplostomum spathaceum (Rudolphi, 1819), Truttaedacnitis clitellarius (Ward \& Magath, 1917), Cystidicoloides ephemeridarum (von Linstow, 1872) (Moravec, 1981).

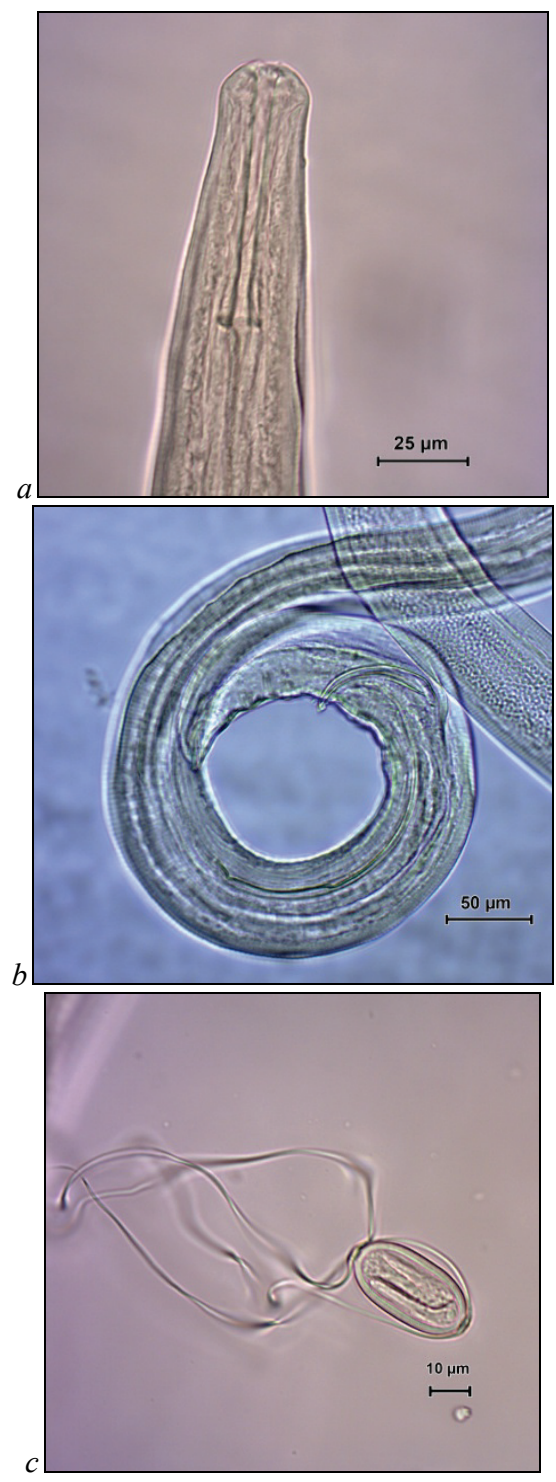

Fig. 4. Capillospirura ovotrichura (Skrjabin, 1924): $a$-head end, $b$ - back end of male, $c$ - egg

We would like to emphasise the rarity of Diclybothrium armatum monogenea in the Siberian sterlet, the parasite being common in other sturgeon species, including the nominative subspecies of sterlet (Zahvatkin, 1938; Volkova, 1941; Petrushevskij et al., 1948; Bauer, 1948, 1959; Shul'man, 1954; Skryabina, 1974). Shul'man (1954) suggests the presence of several mechanisms, either physiological or biochemical, and an ecological peculiarity of the Siberian sterlet subspecies, which prevent infestation with $D$. armatum. This aspect should be studied further.

The species composition of non-specific parasites which occur in sturgeon depends on the local ecological conditions and differs in each particular water body. In water bodies of Siberia (Ob, Yenisei, Lena), sturgeon become infested with species typical for northern fish: Salmonidae, Coregonus and burbot (Shul'man, 1954). This was proved by our 
discovery of the acanthocephalan E. cinctulus. This parasite was recorded for the first time in sterlet of the Ob-Irtysh basin.

Table 2

Species composition of parasites of sterlet in the rivers of Siberia and the extensivity of invasion (\%)

\begin{tabular}{|c|c|c|c|c|c|}
\hline Parasitofauna & $\begin{array}{l}\text { Yenisei } \\
\text { Basin } \\
\text { (Bauer, } \\
\text { 1948; } \\
\text { Skryabina, } \\
\text { 1974 }{ }^{1} \text { ) }\end{array}$ & $\begin{array}{l}\text { R. Irtush } \\
\text { (Petrushevskij } \\
\text { et al., 1948) }\end{array}$ & $\begin{array}{l}\text { Lake Zaysan and } \\
\text { the Black Irtush } \\
\text { ij(Zahvatkin, 1938; } \\
\text { Dobrohotova, } \\
\text { 1960) }\end{array}$ & $\begin{array}{c}\text { R. Ob } \\
\text { (Titova, 1965; } \\
\text { Razmashkin, } \\
1976^{2} \text { ) }\end{array}$ & $\begin{array}{l}\text { Lower Irtysh } \\
\text { (our own } \\
\text { research) }\end{array}$ \\
\hline & \multicolumn{5}{|c|}{ Number of researched specimens of sterlet } \\
\hline & 96 and $2^{1}$ & 40 & 4 & 148 and $5^{2}$ & 85 \\
\hline Hexamita truttae & - & 20.0 & - & - & - \\
\hline $\begin{array}{l}\text { Cryptobia } \\
\text { acipenseris }\end{array}$ & $7.7-33.3$ & - & - & - & 3.5 \\
\hline $\begin{array}{l}\text { Haemogregarina } \\
\text { acipenseris }\end{array}$ & - & - & - & - & 14.1 \\
\hline $\begin{array}{l}\text { Trichodina } \\
\text { domerguei }\end{array}$ & - & 6.6 & - & - & \\
\hline $\begin{array}{l}\text { Trichodina } \\
\text { carassii }\end{array}$ & - & 13.2 & - & - & - \\
\hline Trichodina sp. & & & & & 32.9 \\
\hline $\begin{array}{l}\text { Diclybothrium } \\
\text { armatum }\end{array}$ & * & $*$ & $*$ & - & - \\
\hline $\begin{array}{l}\text { Amphilina } \\
\text { foliacea }\end{array}$ & $20.0-92.4$ & - & - & - & - \\
\hline $\begin{array}{l}\text { Proteocephalus } \\
\text { sp. }\end{array}$ & - & - & - & - & $*$ \\
\hline $\begin{array}{l}\text { Cyathocephalus } \\
\text { truncates }\end{array}$ & $7.7-33.3$ & - & - & - & - \\
\hline $\begin{array}{l}\text { Diplostomum } \\
\text { chomatophorum } \\
\text { mtc }\end{array}$ & - & - & - & - & 5.9 \\
\hline $\begin{array}{l}\text { Diplostomum } \\
\text { spathaceum }\end{array}$ & - & - & - & $*^{2}$ & - \\
\hline $\begin{array}{l}\text { Crepidostomum } \\
\text { auriculatum }\end{array}$ & $\begin{array}{l}30.8- \\
100.0\end{array}$ & 33.0 & * & $10.0-27.0$ & 32.9 \\
\hline $\begin{array}{l}\text { Capillospirura } \\
\text { ovotrichuria }\end{array}$ & $20.0-53.0$ & - & $*$ & - & 15.3 \\
\hline $\begin{array}{l}\text { Truttaedacnitis } \\
\text { clitellarius }\end{array}$ & 15.4 & - & - & 40.0 & - \\
\hline $\begin{array}{l}\text { Cystidicoloides } \\
\text { ephemeridarum }\end{array}$ & - & - & - & 15.0 & - \\
\hline $\begin{array}{l}\text { Echinorhynchus } \\
\text { cinctulus }\end{array}$ & $6.6-23.1$ & - & - & - & $*$ \\
\hline $\begin{array}{l}\text { Echinorhynchus } \\
\text { salmonis }\end{array}$ & $* 1$ & - & - & - & - \\
\hline $\begin{array}{l}\text { Piscicola } \\
\text { geometra }\end{array}$ & $6.6-26.6$ & - & - & - & 10.6 \\
\hline $\begin{array}{l}\text { Ergasilus } \\
\text { sieboldi }\end{array}$ & - & - & - & - & $*$ \\
\hline $\begin{array}{l}\text { Unionidae } \\
\text { gen. sp. }\end{array}$ & 7.0 & - & - & - & $*$ \\
\hline $\begin{array}{c}\text { Total number } \\
\text { of species }\end{array}$ & 11 & 4 & 3 & 4 & 11 \\
\hline
\end{tabular}

Note: * single specimens of the parasite found.

The total number of species recorded for the Siberian sterlet in the Ob-Irtysh basin was higher than that for sterlet from the Yenisei: 18 and 11 respectively (Table 2). The species found in fish of two basins were the following: Cryptobia acipenseris, Diclybothrium armatum, Crepidostomum auriculatum, Capillospirura ovotrichuria, Truttaedacnitis clitellarius, Echinorhynchus cinctulus, Piscicola geometra, Unionidae gen. sp. To a large extent, the interbasin parasitological differences are related to the lower extent of study of parasitofauna of sterlet in the Yenisei. However, the absence of Amphilina foliacea, which is parasite specific to sturgeon, in the Ob-Irtysh basin, and the high infestation with this species in the Yenisei, and also its presence in Siberian sturgeon in the Ob-Irtysh basin indicates that there are other factors.

In the water bodies of Siberia, the species composition of parasites of the Siberian sterlet is significantly poor compared to that of sterlet in the Volga-Caspian basin, where the species is recorded as hosting 44 species of parasites, 20 of which are specific to sturgeon (Kazarnikova $\&$ Shestakovskaya, 2006).

\section{Conclusion}

During the summer of 2017, Acipenser ruthenus marsiglii in the Lower Irtysh basin was found to host 11 species of parasites, the most abundant of which are specific parasites of sturgeon: the trematode $\mathrm{Cre}$ pidostomum auriculatum and the nematode Capillospirura ovotrichura. Compared to the data obtained for this region over 70 years ago (Petrushevskij et al., 1948), infestation of sterlet with Crepidostomum auriculatum almost has not changed, and blood parasites Cryptobia acipenseris and Haemogregarina acipenseris were recorded in the $\mathrm{Ob}-$ Irtysh basin for the first time.

The article was prepared with financial support of the Federal Agency of Scientific Organizations of Russia in the scope of the topic of fundamental scientific research R\&D No AAAA-A17-117041910049-9 "Biodiversity of parasitic communities among the fish population of the Lower Irtysh and species interaction between them".

\section{References}

Akbulut, B., Feledi, T., Lengyel, S., \& Ronyai, A. (2013). Effect of feeding rate on growth performance, food utilization and meat yield of sterlet (Acipenser ruthenus Linne, 1758). Journal of Fisheries Sciences, 7(3), 216-224.

Anderson, R. M., \& Gordon, D. M. (1982). Processes influencing the distribution of parasite numbers within host populations with special emphasis on parasite-induced host mortalities Parasitology, 85(2), 373-398.

Anderson, R. M., \& May, R. M. (1978). Regulation and stability of host-parasite population interactions: I. Regulatory Processes Journal of Animal Ecology, 47(1), 219-247.

Appy, R. G., \& Anderson, R. C. (1982). The genus Capillospirura Skrjabin, 1924 (Nematoda: Cystidicolidae) of sturgeons. Canadian Journal of Zoology, 60(2), 194-202.

Appy, R. G., \& Anderson, R. C. (1982). The genus Capillospirura Skrjabin, 1924 (Nematoda: Cystidicolidae) of sturgeons. Canadian Journal of Zoology, 60(2), 194-202.

Atopkin, D. M., \& Shedko, M. B. (2014). Genetic characterization of far eastern species of the genus Crepidostomum (Trematoda: Allocreadiidae) by means of ${ }^{28} \mathrm{~S}$ ribosomal DNA sequences. Advances in Bioscience and Biotechnology, 5, 209-215.

Baska, F. (1990). Chloromyxum inexpectatum n. sp. and Sphaerospora colomani n. sp. (Myxozoa: Myxosporea) parasites of the urinary system of the sterlet, Acipenser ruthenus L. Systematic parasitology, 16, 185-193.

Bauer, O. N. (1948). Parazity ryb r. Enisej [Fish parasites of the Yenisei River]. Izvestiya VNIORH, 27, 97-157 (in Russian).

Bauer, O. N. (1959). Biologiya Diclybothrium armatum Leuckart (Monogenoidea) - parazita osetrovyh ryb [Biology of Diclybothrium armatum Leuckart (Monogenoidea) - sturgeon parasite]. Voprosy Ekologii, 3, 142-153 (in Russian).

Bauer, O. N., Pugachev, O. N., \& Voronin, V. N. (2002). Study of parasites and diseases of sturgeons in Russia: A review. Journal of Applied Ichthyology, $18,420-429$.

Bush, A. O., Lafferty, K. D., Lotz, J. M., \& Shostak, A. W. (1997). Parasitology meets ecology on its own terms: Margolis et al. revisited. Journal of Parasitology, 83(4), 575-583.

Byhovskaya-Pavlovskaya, I. E. (1985). Parazity ryb. Rukovodstvo po izucheniiyu [Fish parasites. Study Guide]. Nauka, Leningrad (in Russian).

Caira, J. N. (1989). A revision of the North American papillose Allocreadiidae (Digenea) with independent cladistic analyses of larvaland adult forms. Bulletin of the University of Nebraska State Museum, 11, 1-58.

Cakic, P., Djikanovic, V., Kulisic, Z., Paunovic, M., Jakovčev-Todorovic, D., \& Milosevic, S. (2008). The fauna of endoparasite fauna in Acipenser ruthenus Linneaus 1758 from the Serbian part of the Danube River. Archives of Biological Sciences, 60(1), 103-107.

Choudhury, A., \& Dick, T. A. (2001). Sturgeons (Chondrostei: Acipenseridae) and their metazoan parasites: Patterns and processes in historical biogeography. Journal of Biogeography, 28, 1411-1439.

Dobrohotova, O. V. (1960). Parazity ryb oz. Zajsan [Fish parasites of the lake Zaisan]. Trudy Instituta Zoologii Kazahskoj SSR, 14, 109-127 (in Russian).

Dubinin, V. B. (1952). Parazitofauna molodi osetrovyh ryb Nizhnej Volgi [Parasitofauna of juvenile sturgeon fish of the Lower Volga]. Uchenye Zapiski LGU. Seriya Biologicheskie Nauki, 141, 238-251 (in Russian). 
Fedotkina, S. N., \& Shinkarenko, A. N. (2015). Vopros izucheniya gel'mintofauny sterlyadi vodoemov Volgogradskoj oblasti [The study of the helminthofauna of sterlet reservoirs in the Volgograd Region]. Teoriya $i$ Praktika Parazitarnyh Boleznej Zhivotnyh, 16, 453-455 (in Russian).

George, T., \& McCabe, J. (1993). Prevalence of the parasite Cystoopsis acipenseri (Nematoda) in juvenile white sturgeons in the Lower Columbia River. Journal of Aqualic Animal Health, 5, 313-316.

Guénette, S., Rassart, E., \& Fortin, R. (1992). Morphological differentiation of Lake Sturgeon (Acipenser fulvescens) from the St. Lawrence River and Lac des Deux Montagnes (Quebec, Canada). Canadian Journal of Fisheries and Aquatic Sciences, 49(9), 1959-1965.

Israel, J. A., \& May, B. (2010). Indirect genetic estimates of breeding population size in the polyploid green sturgeon (Acipenser medirostris). Molecular Ecology, 19, 1058-1070

Ivanov, V. P. (1968). Parazitofauna osetrovyh ryb pri estestvennom i iskusstvennom ih vosproizvodstve $\mathrm{v}$ izmennenoj Volge [Parasitofauna of sturgeon fishes with natural and artificial reproduction in the changed Volga] Volgograd (in Russian).

Izyumova, N. A. (1977). Parazitofauna ryb vodohranilishch SSSR i puti ee formirovaniya [Parasitofauna of fish in reservoirs of the USSR and ways of its formation]. Nauka, Leningrad (in Russian).

Kazarnikova, A. V., \& Shestakovskaya, E. V. (2006). Sravnitel'nyj analiz fauny parazitov osetrovyh ryb Azovskogo i Kaspijskogo bassejnov. Ehkosistemnye issledovaniya sredy i bioty Azovskogo moria [Comparative analysis of fauna of parasites of sturgeon fish of the Azov and Caspian basins. Ecosystem research of the environment and biota of the Sea of Azov]. MMBI RAN, YUNC RAN, Murmansk, Apatity. Pp. 252-263 (in Russian).

Khan, R. A. (1980). The leech as a vector of a fish piroplasm. Canadian Journal of Zoology, 58(9), 1631-1637.

Lenhardt, M., Jarić, I., Cakić, P., Cvijanović, G., Gačić, Z., \& Kolarević, J. (2009). Seasonal changes in condition, hepatosomatic index and parasitism in sterlet (Acipenser ruthenus L.). Turkish Journal of Veterinary and Animal Sciences, 33(3), 209-214.

Liberman, E. L. (2017). Analiz linejno-vesovyh pokazatelej i meristicheskih priznakov sibirskoj sterlyadi Acipenser ruthenus marsiglii (Brandt, 1833) bassejna reki Irtysh [Analysis of linear-weight indicators and meristic characters of the siberian sterlet Acipenser ruthenus marsiglii (Brandt, 1833 ) in the Irtish river basin]. Vestnik AGTU, 64, 83-89 (in Russian).

Lyubarskaya, O. D., \& Lavrent'eva, Y. I. (1985). Parazitofauna sterlyadi Srednej Volgi i Kujbyshevskogo vodohranilishcha [The parasitofauna of the sterlet of the Middle Volga and the Kuibyshev reservoir]. Parazitologiya, 19(4), 320-323 (in Russian).

Marcogliese, D. J., Dumont, P., Gendron, A. D., Mailhot, Y., Bergeron, E., \& McLaughlin, J. D. (2001). Spatial and temporal variation in abundance of Diplostomum spp. in walleye (Stizostedion vitreum) and white suckers (Catostomus commersoni) from the St. Lawrence River. Canadian Journal of Zoology, 79(3), 355-369.

May, R. M., \& Anderson, R. M. (1978). Regulation and stability of host-parasite population interactions: II. Destabilizing Processes Anderson Journal of Animal Ecology, 47(1), 249-267.

Moravec, F. (2013). Parasitic nematodes of freshwater fishes of Europe. Academia, Praha.

Opredelitel' parazitov presnovodnyh ryb fauny SSSR (1984). Paraziticheskie prostejshie [The determinant of parasites of freshwater fish of the USSR (1984). Parasitic Protozoa]. Nauka, Leningrad. Vol. 1 (in Russian).

Opredelitel' parazitov presnovodnyh ryb fauny SSSR (1987). Paraziticheskie mnogokletochnye [The determinant of parasites of freshwater fish fauna of the USSR. Parasitic multicellular]. Nauka, Leningrad. Vol. 3 (in Russian).
Pazooki, J., \& Masoumian, M. (2004). Cryptobia acipenseris and Haemogregarina acipenseris infections in Acipenser guldenstadti and A. persicus in the southern part of the Caspian Sea. Journal of Agricultural Science and Technology, 6, 95-101.

Perekropov, T. I. (1930). Haemogregarinen beim Wolga und Kama Sterlet (Acipenser ruthensis). Zentralblatt für Bakteriologia, 80, 253-259.

Petrushevskij, G. K., Mosevich, M. V., \& Shchupakov, I. G. (1948). Fauna parazitov Obi i Irtysha [Fauna of the parasites of the $\mathrm{Ob}$ and the Irtysh]. Izvestiya VNIORH, 27, 67-97 (in Russian).

Razmashkin, D. A. (1976). O lichinkah trematod, parazitiruyushchih u ryb vodoemov Ob'-Irtyshskogo bassejna. Bolezni i parazity ryb Ledovitomorskoj provincii (v predelah SSSR) [On the larvae of trematodes parasitizing fish of the reservoirs of the Ob-Irtysh basin. Diseases and parasites of fish from the Arctic Ocean (within the USSR)]. Sverdlovsk. Pp. 80-103 (in Russian).

Sepúlveda, M. S., Stefanavage, T., \& Goforth, R. (2010). First record of a Polypodium sp. parasitizing eggs of Shovelnose Sturgeon from the Wabash River, Indiana. Journal of Aquatic Animal Health, 22, 36-38.

Shul'man, S. S. (1954). Obzor fauny parazitov osetrovyh ryb [Overview of fauna of parasites of sturgeon]. Zoologicheskij Zhurnal, 33(1), 190-254 (in Russian).

Skryabina, E. S. (1974). Gel'minty osetrovyh ryb (Acipenseridae Bonaparte, 1831) [Helminths of sturgeon fishes (Acipenseridee Bonaparte, 1831)]. Nauka, Moscow (in Russian).

Soldanova, M., Georgieva, S., Rohacova, J., Knudsen, R., Kuhn, J. A., Henriksen, E. H., Siwertsson, A., Shaw, J. C., Kuris, A. M., Amundsen, P. A. Scholz, T., Lafferty, K. D., \& Kostadinova, A. (2017). Molecular analyses reveal high species diversity of trematodes in a sub-Arctic lake. International Journal for Parasitology, 47, 327-345.

Strel'nikova, A. P. (2012). Feeding of juvenile sterlet (Acipenser ruthenus, Acipenseridae) in the Danube River midstream. Journal of Ichthyology, 52(1), 85-90.

Titova, S. D. (1965). Parazity ryb Zapadnoj Sibiri [Fish parasites of Western Siberia]. Izdatel'stvo Tomskogo Universiteta, Tomsk (in Russian).

Vasil'ev, V. P., Rachek, E. I., Lebedeva, E. B., \& Vasil'eva, E. D. (2014). Karyological study in backcross hybrids between the sterlet, Acipenser ruthenus, and kaluga, $A$. dauricus (Actinopterygii: Acipenseriformes: Acipenseridae): A. ruthenus $\times(A$. ruthenus $\times$ A. dauricus $)$ and $A$.dauricus $\times$ (A. ruthenus $\times$ A. dauricus). Acta Ichthyologica et Piscatoria, 44(4), 301-308.

Volkova, M. M. (1941). Parazitofauna ryb bassejna r. Obi [Parasitofauna of fish in the Ob River Basin]. Uchenye Zapiski LGU, 74(18), 20-36 (in Russian).

Voutilainen, A., Figueiredo, K., \& Huuskonen, H. (2008). Effects of the eye fluke Diplostomum spathaceum on the energetics and feeding of Arctic charr Salvelinus alpines. Journal of Fish Biology, 73(9), 2228-2237.

Woo, P. T. K. (2003). Cryptobia (Trypanoplasma) salmositica and salmonid cryptobiosis. Journal of Fish Diseases, 26, 627-646.

Woo, P. T. K. (2006). Fish diseases and disorders. Protozoan and Metazoan infections. CABI, 1, 191-194.

Wuertz, S., Reiser, S., Gessner, J., \& Kirschbaum, F. (2011). Morphological distinction between juvenile stages of the european sturgeon Acipenser sturio and the atlantic sturgeon Acipenser oxyrinchus. Biology and Conservation of the European Sturgeon Acipenser sturio L. 1758. Pp. 53-64.

Zahvatkin, V. A. (1938). Parazitofauna ryb oz. Zajsan i r. Chernogo Irtysha [Parasitofauna of fish of the Lake. Zaisan and the river. Black Irtysh]. Uchenye Zapiski Permskogo Universiteta, 3(2), 193-249 (in Russian).

Zhuravlev, V. B. (2000). K voprosu o taksonomicheskom statuse sterlyadi Acipenser ruthenus reki Obi [On the question of the taxonomic status of the sterlet Acipenser ruthenus of the Ob River]. Izvestiya Altajskogo Gosudarstvennogo Universiteta, 3, 77-88 (in Russian). 